\title{
Occupational Health (OH) Practices in South African Construction
}

\author{
John Smallwood ${ }^{1 *}$, and Claire Deacon ${ }^{1}$ \\ ${ }^{1} \mathrm{~N}$ el son $\mathrm{M}$ andela University, D epartment of Construction M anagement, PO B ox 77000, \\ Port Elizabeth, 6031, South A frica
}

\begin{abstract}
Health hazards in construction include: ergonomic stresses such as bending, lifting and repetitive movement and vibration; environmental stresses such as heat, sun, noise, poor illumination, and wet or damp work; skin and respiratory exposure to chemicals and dust, as well as mental stress among managers, supervisors, and workers. In South A frica, these may add to the health problems experienced by construction workers because of poor community health, substance abuse, and inadequate health services. A selfadministered questionnaire survey was conducted among the professional category of construction health and safety $(H \& S)$ practitioners to determine $\mathrm{OH}$ issues in construction. Findings include: the extent to which $\mathrm{OH}$ aspects were identified by respondents on projects in 2017 indicates that construction entails exposure to a range of $\mathrm{OH}$ hazards and risk; the degree of $\mathrm{OH}$ knowledge and awareness is limited as opposed to extensive; the source of $\mathrm{OH}$ knowledge is informal; there is a need for $\mathrm{OH}$ to be embedded in tertiary built environment programmes, $\mathrm{OH}$ continuing professional development (CPD), and a construction industry $\mathrm{OH}$ standard, and $\mathrm{OH}$ practice notes.
\end{abstract}

Keywords: construction, health and safety, occupational diseases, $\mathrm{OH}$, W orker health and well being

\section{Introduction}

Ill health kills and ruins lives in the construction industry. A construction worker is at least 100 times more likely to die from a disease that has been caused or exacerbated from their work, than from a fatal accident [1-4]. Construction work itself is known as dirty, tough and hazardous, highly manual, and transient in nature. Further to the conditions, approximately $30 \%$ of workers are transient in nature [5].

$\mathrm{NIOH}[4]$ state that occupational or work-related diseases are caused by exposure to occupational hazards during a contract of employment. NIOH [4] further cites the construction industry as one of three industries with the highest rate of work-related injury risks. Hazards that workers are exposed to include chemical, biological, poor ergonomics,

\footnotetext{
* Corresponding author: john.smallwood@mandela.ac.za
} 
and psychosocial hazards. Extended exposure to such risks results in occupational and workrelated diseases [4].

The South African Constitution [6], as the over-arching legislation, enshrines several rights that could be linked to the rights of workers in the context of this paper. Section 24 states: "Everyone has a right to an environment that is not harmful to their health" [5].

The OH and Safety Act (OHSA) No. 85 of 1993 requires employers to comply with the rights of citizens as stated in the Constitution, as they relate to employees. Employers have a further responsibility as it relates to those directly affected by activities, and are expected to ensure that all equipment and substances designed for use are safe and without risk to health. While these duties apply to the working environment, in many cases, accommodation could be adjacent, within or close to the construction works Smallwood and Deacon $[3,5]$.

Given the aforementioned, a study was conducted to determine:

- $\quad$ The perceptions of CHSAs with respect to project $\mathrm{OH}$;

- CHSAs' project OH related practices;

- The potential of interventions to contribute to an improvement in project $\mathrm{OH}$, and

- CHSAs' source of construction $\mathrm{OH}$ knowledge.

\section{Review of the Literature}

\subsection{Construction Health and Safety}

While the focus is generally on the safety end of $\mathrm{H} \& \mathrm{~S}$, the management of $\mathrm{OH}$ risks is no different from that of safety. $\mathrm{OH}$ risks should be identified and managed using risk assessments, to take sensible and proportionate measures to control such risks. A range of $\mathrm{OH}$ and $H \& S$ specialists are generally involved in identifying and managing health risks [2].

According to Obiozo and Smallwood [7], the well-being and performance of construction workers is an issue at several structural levels. The physical state of the site directly affects health, and at the organisational level, overall performance, through the environment, H\&S, and the traditional parameters of construction, namely cost, quality, and time. Construction activities could occur in isolated locations, or in the middle of heavy traffic. There could, furthermore, be up to 20 contractors on a single project, increasing the complexity of project management.

\subsection{Practices and Responsibilities among Construction Health and Safety Professionals}

Enabling legislation from the South African Council for the Project and Construction Management Professions (SACPCMP) has outlined the need for anyone practising in H\&S in the construction industry to be registered in one of three categories. Such categories include the construction H\&S Officer (CHSO), Manager (CHSM), and the professional category as agent (Pr CHSA). Each of the roles has different deliverables, with a clear scope of work. The Pr CHSA practices across all six stages of construction, and the CHSO and CHSM during stages four to six. The six stages of construction are:

1. Project initiation and briefing;

2. Concept and feasibility;

3. Design development;

4. Tender Documentation and procurement;

5. Construction documentation and management, and

6. Project Closeout [8]. 
Smallwood and Deacon [8] indicate that the role of the Pr CHSA decreases in efficacy the later their appointment. Most are only appointed during stages four or five, which limits the ability to ensure that $\mathrm{H} \& \mathrm{~S}$ risks relative to design are identified and mitigated as far as possible.

\subsection{Designing for Construction Health \& Safety}

Generally, in managing risks to workers the hierarchy of control is widely practised in industry. The hierarchy essentially attempts to find the earliest point of action to reduce risk. Elimination of the activity or process would be the highest level of action, however, if elimination is not an option, then to substitute is the next option. Engineering options such as encasing or exhaust systems, administration through safe working practices and finally allowing personal protective equipment (PPE) to be used $[2,3,9]$.

In construction, the actions during stage 3 or design are the earliest opportunity to apply the hierarchy of control. There are several methods and processes that could be considered that do not only determine the risks to construction workers during construction (stage 5) but also the life cycle of the structure that could affect those working there. The Pr CHSA, if appointed at the earliest point (stage 1), can reduce risk at the earliest opportunity [3].

\section{Occupational Health}

$\mathrm{OH}$ is defined by the World Health Organization (WHO) as "the promotion and maintenance of the highest degree of physical, mental and social well-being of workers in all occupations by preventing departures from health, controlling risks and the adaptation of work to people to their jobs" $[10,11]$.

The lack of understanding of what $\mathrm{OH}$ is, the role and the benefits thereof are mostly misunderstood. During the construction of the Olympic Park in London, Park Health, who provided the $\mathrm{OH}$ services, described occupational damage as 'the slow accident', which illustrated the effects of exposure are slow-moving, but just as dramatic as an accident [2].

The benefits of $\mathrm{OH}$ related interventions at work are numerous: workers feel valued, motivated to keep fit to carry out their work, and their own health; an increase in life expectancy and quality of health; have a positive impact on attitudes and behaviour towards health risks and further provides an opportunity to coach workers regarding H\&S risks at work [2].

\subsection{Occupational Exposures}

In most cases occupational disease and illness can be prevented, provided risks are identified, managed, and controlled. Managing the ill health effects of occupational exposure is not an instant fix, like placing a dressing on a cut to a finger. Occupational diseases manifest years following exposure, asbestos, for example, could take up to 40 years to present with an asbestos-related disease [2].

Construction workers are exposed to many forms of hazards that cause target organ damage that is considered as an occupational disease (OD). For example, crystalline silica, as dust, affects the respiratory system, mainly the lungs (the target organ), causing silicosis (an occupational disease). Exposure to asbestos also affects mainly the lungs, and causes severe damage and fibrosis of the lung tissue, and is diagnosed as asbestosis (Center to Protect Workers Rights (CPWR).

Different forms of work expose workers to risks. Fumes from welding and soldering; dust from cutting, drilling stone and various materials, gasses, and waste products. Several natural 
hazards are a further risk to which workers are exposed, such as biological hazards (legionella, zoonoses), temperatures and weather, spores, and sunlight [2].

\subsection{Ergonomic Factors}

Construction work is physically demanding, with workers required to adopt awkward body postures, while frequently required to manually handle materials and products during a workday. While it is important to train workers in ergonomic factors, training alone is not deemed effective without determining interventions to limit the effects of such work. Ergonomic interventions are better addressed during the design stages but should consider the life cycle of the project $[12,13]$.

\subsection{Occupational Hygiene Monitoring}

The monitoring of measuring the extent of exposure is the responsibility of the Occupational Hygienist. The Occupational Hygienist collects data to measure the extent of physical and chemical risks, which in turn is used to determine how risks are to be mitigated and managed, or measured for effectiveness following mitigation. An example includes conducting of noise, dust and chemical surveys against a set of strictly defined criteria that are set internationally [2].

\subsection{Medical Surveillance}

Medical surveillance is also termed health surveillance. However, the purpose is the same. Botha, Ross and Michell [14] cite Rogers, who defines medical surveillance as "the systematic and ongoing analysis, collection and evaluation of employee health data to identify specific instances of illness or health trends suggesting an adverse effect of illness or health trends suggesting an adverse effect of workplace exposures." The purpose of conducting medical surveillance, therefore, considers a variety of appropriate times to conduct surveillance. Most commonly, surveillance is done at pre-employment or preplacement, periodically according to legislative requirements (such as when exposed to noise above $85 \mathrm{~dB}(\mathrm{a})$ ), and when exiting employment [2]. Botha et al. [14], and IOSH [2], state that surveillance is done to assess the workers' ability or fitness to work, relative to the risks they are likely to be exposed to or to determine previous exposure that could place them at risk. Generally, the greater the risk, the more frequent the surveillance.

\section{Research}

\subsection{Research Method and Sample Stratum}

A survey involving a questionnaire was sent to all SACPCMP registered Pr CHSAs throughout South Africa, per e-mail. Out of the 72 invited to participate, only 20 responses were returned, despite following up with the sample stratum, which equates to a response rate of $27.8 \%$. Due to the low response rate, the findings are deemed to be indicative, but likely to be from the more committed practitioners. Respondents indicated that their experience since 2017 included the infrastructure sector $(44.7 \%)$, the industrial sector (25.1\%), commercial sector $(13.7 \%)$, and the residential sector $(9.6 \%)$. 


\subsection{Research Results}

Table 1 indicates the importance of addressing $\mathrm{OH}$ during the six stages of projects in terms of percentage responses to a scale of 1 (not important) to 5 (very important), and a mean score (MS) ranging between 1.00 and 5.00. It is notable that all the MSs are above the midpoint of 3.00, which indicates that in general, the respondents perceive the addressing of $\mathrm{OH}$ during the six project stages to be important. The MSs of design development (stage 3), construction documentation and management (stage 5), and concept and feasibility (stage 2) are $>4.20 \leq 5.00$ - between more than important to very important / very important. Tender documentation and procurement (stage 4), project initiation and briefing (stage 1), and project closeout (stage 6 ) in turn fall within the range $>3.40 \leq 4.20$ - between important to more than important / more than important.

Table 1. The importance of addressing $\mathrm{OH}$ during the six stages of projects.

\begin{tabular}{|c|c|c|c|c|c|c|c|c|}
\hline \multirow{3}{*}{ Stage } & \multicolumn{6}{|c|}{ Response (\%) } & \multirow{3}{*}{ MS } & \multirow{3}{*}{ Rank } \\
\hline & \multirow{2}{*}{$\begin{array}{l}\text { Un- } \\
\text { sure }\end{array}$} & \multicolumn{5}{|c|}{ Not ................................. Very } & & \\
\hline & & 1 & 2 & 3 & 4 & 5 & & \\
\hline Design development & 0.0 & 0.0 & 5.0 & 10.0 & 25.0 & 60.0 & 4.40 & 1 \\
\hline $\begin{array}{c}\text { Construction } \\
\text { documentation and } \\
\text { management }\end{array}$ & 0.0 & 5.0 & 0.0 & 5.0 & 30.0 & 60.0 & 4.40 & 2 \\
\hline Concept and feasibility & 0.0 & 0.0 & 10.5 & 10.5 & 26.3 & 52.6 & 4.21 & 3 \\
\hline $\begin{array}{l}\text { Tender documentation } \\
\text { and procurement }\end{array}$ & 0.0 & 0.0 & 10.0 & 10.0 & 40.0 & 40.0 & 4.10 & 4 \\
\hline $\begin{array}{l}\text { Project initiation and } \\
\text { briefing }\end{array}$ & 0.0 & 5.3 & 5.3 & 21.1 & 26.3 & 42.1 & 3.95 & 5 \\
\hline Project close out & 0.0 & 5.3 & 10.5 & 10.5 & 36.8 & 36.8 & 3.89 & 6 \\
\hline
\end{tabular}

Table 2 indicates the extent to which $\mathrm{OH}$ aspects were identified by respondents on projects in 2017 . All thirty aspects were identified by more than $50 \%$ of respondents, twenty-four $(80 \%)$ by $\geq 75 \%$, and nine $(30 \%)$ by $90 \%$. Manual tasks $(100 \%)$ predominate, and was followed jointly ( $94.7 \%$ ) by oils/petrol (hydrocarbons), paints, cement dust, concrete dust, labour-intensive work, noise, and vibration. These aspects were followed closely by heat $(90 \%)$, jointly $(89.5 \%)$ by solvents, mechanised methods (potential), and work pressure. In terms of the percentage of projects on which $\mathrm{OH}$ aspects were specified, the highest mean was relative to cement dust $(75.8 \%)$, followed by concrete dust $(72.8 \%)$, labour intensive work $(71.9 \%)$, manual tasks $(70.5 \%)$, oils/petrol (hydrocarbons) $(66.7 \%)$, and block/brick dust (61.9\%).

Table 2. The extent to which aspects were identified on projects in 2017.

\begin{tabular}{ccccccc}
\hline \multirow{2}{*}{ Aspect } & \multicolumn{3}{c}{ Response (\%) } & \multicolumn{3}{c}{ Percentage of projects } \\
\cline { 2 - 7 } & Unsure & Did not & Yes & Lowest & Highest & Mean \\
\hline Manual tasks & 0.0 & 0.0 & 100.0 & 10.0 & 100.0 & 70.5 \\
Oils / Petrol (hydrocarbons) & 0.0 & 5.3 & 94.7 & 2.0 & 100.0 & 66.7 \\
Paints & 0.0 & 5.3 & 94.7 & 15.0 & 100.0 & 58.7 \\
Cement dust & 0.0 & 5.3 & 94.7 & 10.0 & 100.0 & 75.8 \\
Concrete dust & 0.0 & 5.3 & 94.7 & 10.0 & 100.0 & 72.8 \\
Labour intensive work & 0.0 & 5.3 & 94.7 & 25.0 & 100.0 & 71.9 \\
Noise & 0.0 & 5.3 & 94.7 & 5.0 & 100.0 & 53.2 \\
Vibration & 0.0 & 5.3 & 94.7 & 5.0 & 100.0 & 46.5 \\
Heat & 0.0 & 10.0 & 90.0 & 5.0 & 100.0 & 52.9 \\
Solvents & 0.0 & 10.5 & 89.5 & 5.0 & 100.0 & 57.2
\end{tabular}




$\begin{array}{ccccccc}\text { Mechanised methods } & 0.0 & 10.5 & 89.5 & 10.0 & 100.0 & 52.5 \\ \text { (potential) } & 5.3 & 5.3 & 89.5 & 5.0 & 100.0 & 53.2 \\ \text { Work pressure } & 0.0 & 15.0 & 85.0 & 5.0 & 100.0 & 43.5 \\ \text { Bitumen } & 0.0 & 15.8 & 84.2 & 5.0 & 100.0 & 48.8 \\ \text { Fumes } & 0.0 & 15.8 & 84.2 & 5.0 & 100.0 & 44.3 \\ \text { Adhesives } & 5.3 & 10.5 & 84.2 & 5.0 & 100.0 & 55.1 \\ \text { Vapours } & 0.0 & 16.7 & 83.3 & 10.0 & 100.0 & 30.0 \\ \text { Epoxy-resins } & 0.0 & 16.7 & 83.3 & 5.0 & 100.0 & 41.9 \\ \text { Cold } & 0.0 & 16.7 & 83.3 & 4.0 & 100.0 & 45.3 \\ \text { Quartz / Silica dust } & 0.0 & 21.1 & 78.9 & 5.0 & 70.0 & 25.0 \\ \text { Asbestos dust } & 0.0 & 21.1 & 78.9 & 10.0 & 100.0 & 61.9 \\ \text { Block / Brick dust } & 0.0 & 21.1 & 78.9 & 5.0 & 100.0 & 45.4 \\ \text { Shift work } & 5.3 & 15.8 & 78.9 & 5.0 & 100.0 & 42.5 \\ \text { Illumination (Poor) } & 0.0 & 25.0 & 75.0 & 5.0 & 100.0 & 46.4 \\ \text { Insects } & 0.0 & 26.3 & 73.7 & 10.0 & 100.0 & 34.6 \\ \text { Waterproofing } & 10.5 & 15.8 & 73.7 & 5.0 & 100.0 & 51.8 \\ \text { Monotony } & 10.5 & 15.8 & 73.7 & 15.0 & 100.0 & 55.7 \\ \text { Stress } & 10.5 & 15.8 & 73.7 & 5.0 & 100.0 & 42.5 \\ \text { Unsociable hours } & 0.0 & 42.1 & 57.9 & 5.0 & 100.0 & 35.1 \\ \text { Viruses } & 11.1 & 33.3 & 55.6 & 5.0 & 100.0 & 35.0 \\ \text { Mineral wools } & & & & & & \end{array}$

Table 3 indicates the extent to which environmental measurement was specified by respondents on projects in 2017. All environmental measurements were identified by more than $50 \%$ of respondents. Noise $(85 \%)$ predominates, followed by air quality (ventilation), illumination, and dust (silica).

In terms of the percentage of projects on which environmental measurement was specified, the highest mean was relative to noise $(55 \%)$, followed closely by dust (silica) $(49 \%)$. The lowest was relative to air quality (ventilation) $(0 \%)$, and the highest $(100 \%)$ relative to all measurements.

Table 3. The extent to which environmental measurement was specified by respondents on projects in 2017.

\begin{tabular}{ccccccc}
\hline \multirow{2}{*}{ Measurement } & \multicolumn{3}{c}{ Response (\%) } & \multicolumn{3}{c}{ Percentage of projects } \\
\cline { 2 - 7 } & Unsure & No & Yes & Lowest & Highest & Mean \\
\hline Noise & 0.0 & 15.0 & 85.0 & 5.0 & 100.0 & 55.0 \\
Air quality (ventilation) & 0.0 & 31.6 & 68.4 & 0.0 & 100.0 & 33.4 \\
Illumination & 0.0 & 31.6 & 68.4 & 10.0 & 100.0 & 33.1 \\
Dust (silica) & 0.0 & 36.8 & 63.2 & 5.0 & 100.0 & 49.0 \\
\hline
\end{tabular}

Table 4 indicates the extent to which $\mathrm{OH}$ related interventions were specified by respondents on projects in 2017. All $\mathrm{OH}$ related interventions were identified by more than $50 \%$ of respondents. Pre-employment medicals $(85 \%)$ predominate, followed jointly (84\%) by annual in-employment (periodic) medicals, and plant operator medicals.

Table 4. The extent to which $\mathrm{OH}$ related interventions were specified by respondents on projects in 2017.

\begin{tabular}{ccccccc}
\hline \multirow{2}{*}{ Intervention } & \multicolumn{3}{c}{ Response (\%) } & \multicolumn{3}{c}{ Percentage of projects } \\
\cline { 2 - 7 } & Unsure & No & Yes & Lowest & Highest & Mean \\
\hline Pre-employment medicals & 0.0 & 15.0 & 85.0 & 50.0 & 100.0 & 97.1 \\
Annual in-employment (periodic) & 0.0 & 15.8 & 84.2 & 5.0 & 100.0 & 92.5 \\
medicals & 0.0 & 15.8 & 84.2 & 25.0 & 100.0 & 92.2 \\
Plant operator medicals & 5.3 & 15.8 & 78.9 & 5.0 & 100.0 & 83.0
\end{tabular}




\begin{tabular}{ccccccc} 
Contract specific (client required) & 0.0 & 21.1 & 78.9 & 15.0 & 100.0 & 89.0 \\
medicals & 0.0 & 36.8 & 63.2 & 60.0 & 100.0 & 96.7 \\
Exit medicals medicals & 0.0 & 38.9 & 61.1 & 5.0 & 100.0 & 91.4 \\
Exit audiometric tests & 0.0 & 47.4 & 52.6 & 10.0 & 100.0 & 63.0 \\
\hline
\end{tabular}

Table 5 indicates the respondents' self-rating of their knowledge of various $\mathrm{OH}$ related aspects in terms of percentage responses to a scale of 1 (limited) to 5 (extensive), and an MS ranging between 1.00 and 5.00. It is notable that all the MSs are above the midpoint of 3.00, which indicates that in general, the respondents rate their knowledge of various $\mathrm{OH}$ related aspects as above average. It is notable that they rate their knowledge relative to all the $\mathrm{OH}$ related aspects as between average to more than average / more than average (MSs > 3.40 $\leq$ 4.20). It is notable that construction $\mathrm{OH}$ is ranked first $(\mathrm{MS}=4.00)$, whereas 'designing for construction $\mathrm{OH}^{\prime}$ ' is ranked last ( $\left.\mathrm{MS}=3.50\right)$, as in the case of the latter, design development was ranked first in terms of the importance of addressing $\mathrm{OH}$ during the six stages of projects, and design development was ranked first in terms of the extent to which $\mathrm{OH}$ can be influenced during the six stages of projects.

Table 5. Respondents' self-rating of their knowledge of various $\mathrm{OH}$ related aspects.

\begin{tabular}{|c|c|c|c|c|c|c|c|c|}
\hline \multirow{2}{*}{ Aspect } & \multirow{2}{*}{ Unsure } & \multicolumn{5}{|c|}{ Limited.......................Extensive } & \multirow{2}{*}{ MS } & \multirow{2}{*}{ Rank } \\
\hline & & 1 & 2 & 3 & 4 & 5 & & \\
\hline Construction $\mathrm{OH}$ & 0.0 & 0.0 & 5.3 & 15.8 & 52.6 & 26.3 & 4.00 & 1 \\
\hline $\begin{array}{c}\text { Knowledge of appropriate } \\
\text { protection equipment for } \\
\text { categories of workers linked to } \\
\text { risk }\end{array}$ & 0.0 & 0.0 & 5.0 & 20.0 & 60.0 & 15.0 & 3.85 & 2 \\
\hline $\begin{array}{l}\text { Identification of adequacy of } \\
\text { certificate of fitness }\end{array}$ & 0.0 & 0.0 & 5.0 & 25.0 & 50.0 & 20.0 & 3.85 & 3 \\
\hline $\begin{array}{l}\text { Linking exposure to determining } \\
\text { adequate identification of risks } \\
\text { for the Annexure } 3\end{array}$ & 0.0 & 0.0 & 10.0 & 20.0 & 55.0 & 15.0 & 3.75 & 4 \\
\hline $\begin{array}{l}\text { Limitation or management of } \\
\text { workers deemed limited or unfit } \\
\text { for work }\end{array}$ & 0.0 & 0.0 & 5.0 & 30.0 & 55.0 & 10.0 & 3.70 & 5 \\
\hline $\mathrm{OH}$ & 0.0 & 0.0 & 15.8 & 21.1 & 52.6 & 10.5 & 3.58 & 6 \\
\hline Designing for construction $\mathrm{OH}$ & 0.0 & 0.0 & 15.0 & 25.0 & 55.0 & 5.0 & 3.50 & 7 \\
\hline
\end{tabular}

Respondents indicated that experience $(20.2 \%)$ predominates in terms of the source of their knowledge of $\mathrm{OH}$, followed by workshops (15.5\%), tertiary education $(14.9 \%)$, magazine articles $(11.9 \%)$, and journal papers $(10.7 \%)$. The remaining five sources were identified by less than $10 \%$ of respondents. Clearly, the source of knowledge of $\mathrm{OH}$ is informal as opposed to formal.

A total of $8.3 \%$ respondents indicated they had post-graduate qualifications, and $14.9 \%$ had tertiary education.

\section{Conclusions}

Although the number of respondents was limited, and therefore the findings can be deemed indicative, the respondents are above average in terms of their $\mathrm{OH}$ knowledge, which increases the reliability of the findings. However, the respondents' source of $\mathrm{OH}$ knowledge is more informal than formal, which leads to the conclusion that $\mathrm{OH}$ is not addressed to the extent that it should be in their formal education programmes. 
The respondents perceive the addressing of $\mathrm{OH}$ during the six project stages as important, and therefore understand and appreciate the role of upstream interventions. The respondents further understand and appreciate that $\mathrm{OH}$ can be influenced during the six stages of the construction process.

The extent to which $\mathrm{OH}$ aspects were identified by respondents on projects in 2017 leads to the conclusion that construction entails exposure to a range of $\mathrm{OH}$ hazards and risk. It was noted that the respondents undertake a range of $\mathrm{OH}$ related interventions, including environmental measurement, medicals and tests, and $\mathrm{OH}$ related training.

Finally, it is concluded that $\mathrm{OH}$ is a multi-stakeholder issue.

\section{Recommendations}

Recommendations include, among others, that tertiary built environment education should address $\mathrm{OH}$. Designing for construction $\mathrm{OH}$ should be introduced and more importantly, embedded in tertiary built environment education programmes, especially designer related, and a construction industry $\mathrm{OH}$ standard, $\mathrm{OH}$ practice notes, and CPD should be evolved to guide the sector.

Construction Project Managers and CHSAs must ensure that all stakeholders address $\mathrm{OH}$, and that project $\mathrm{H} \& \mathrm{~S}$ plans focus thereon. Employer associations must afford $\mathrm{OH}$ the requisite recognition in their industry $\mathrm{H} \& \mathrm{~S}$ programmes, star grading process, and regional and national $\mathrm{H} \& \mathrm{~S}$ competitions.

\section{References}

1. D. Snashall, Hazards of Work, in E. Snashall, D. Patel (Eds.), A BC of Occupational and Environmental M edicine, 3rd ed. (John W iley and Sons, U nited Kingdom, 2012)

2. Institute of Occupational Safety and Health (IOSH), OH risk management in construction. A guide to the key issues of OH provision (IOSH, U nited K ingdom, 2016)

3. C.H. Deacon, The Effect of the Integration of Design, Procurement, and Construction relative to Health and Safety, PhD Thesis (Nel son M andela M etropolitan University, South A frica, 2016)

4. National Institute of $\mathrm{OH}(\mathrm{NIOH}), \mathrm{OEHS}$ in the Construction Industry (2018), http://www.nioh.ac.za/?page=construction_industry\& id=190

5. J.J. Smallwood, C.H. Deacon, Construction Camps in Building and Civil Engineering Construction, in Proceedings of the 2nd International Conference on Development and Investment in Infrastructure - Strategies for A frica. 16-18 September 2015, L ivingstone, Zambia. U niversity of J ohannesburg, Johannesburg, South A frica, 201223 (2015)

6. Republic of South A frica, The Constitution of the Republic of South Africa (Government Printer, Pretoria, 1996)

7. R.N. Obiozo, J.J. Smallwood, Rethinking Construction: The Transformational Change Strategy of a Biophilic Construction Site Experience, in E. Fidel is (Ed.), Conference Proceedings Second N M M U Construction M anagement Conference, 25-27 N ovember, 2012, Port Elizabeth, South A frica. N el son M andela M etropolitan University, Port Elizabeth, South A frica, 121-130 (2012)

8. J.J. Smallwood, C.H. Deacon, Construction Health and Safety Agents (CHSAs') contribution to health and safety in South Africa, in Proceedings 7th W est A frica Built Environment Research (W A B ER) Conference, 16-18 A ugust 2017, U niversity of Ghana, A ccra, Ghana, 502-513 (2017) 
9. R. M CCaig, Physical Agents, in E. Snashall, D. Patel (Eds.), A BC of Occupational and Environmental M edicine, 3rd ed. (J ohn W iley and Sons, U nited K ingdom, 2012)

10. A. A disesh, Practising $O H$, in E. Snashall, D. Patel (Eds.), A BC of Occupational and Environmental M edicine, 3rd ed. (J ohn W iley and Sons, U nited K ingdom, 2012)

11. L. J ansen van Rensburg, K. M ichell, K., Models of OH Service Delivery, in K. M ichelle (Ed.), A practical approach to $\mathrm{OH}$ Nursing (South A frican Society of $\mathrm{OH}$ N ursing Practitioners, W ilpro Printers, J ohannesburg, 2011)

12. J.J. Smallwood, Construction ergonomics: A support work manufacturer's perceptions and practices, in Proceedings of International Commission of $\mathrm{OH}(\mathrm{ICOH}): \mathrm{OH}$ and Well being: linking research to practice. Poster presentation. $29 \mathrm{~A}$ pril to $4 \mathrm{M}$ ay 2018 , ICOH, Dublin, Ireland (2018)

13. S. V isser, H.F. van der M olen, J.K. Sluiter, M.H.W . Frings-Dresen, The process evaluation of two alternative participatory ergonomics intervention strategies for construction companies (2018), https://www.tandfonline.com/doi/full/10.1080/ 00140139.2018.1454514

14. L. B otha, M. Ross, K. M ichell, Health Surveillance in $O H$, in K. M ichelle (E d.), A practical approach to $\mathrm{OH}$ Nursing (South A frican Society of $\mathrm{OH}$ N ursing Practitioners, Wilpro Printers, J ohannesburg, 2012) 